\title{
Health and safety conditions based on teacher education. An analysis from bibliometrics
}

Las condiciones en seguridad y salud basada en la formación docente. Un análisis desde la bibliometría

Condições de saúde e segurança na formação de professores. Uma análise bibliométrica

\section{Alba Biviana Montoya Rabelo}

Student, Corporación Universitaria Minuto de Dios, Bogota, Colombia, https://orcid.org/0000-0001-9868-7522 amontoyarab@uniminuto.edu.co

\section{Sandra Julieth Salamanca Reyes}

Student, Corporación Universitaria Minuto de Dios, , Bogota, Colombia, https://orcid.org/0000-0002-5961-9954, ssalamanca5@uniminuto.edu.co

\section{Leidy Isabel Calderon Sierra}

Master, Corporación Universitaria Minuto de Dios, , Bogota, Colombia, https://orcid.org/0000-0002-1056-901X, leidy.calderon@uniminuto.edu

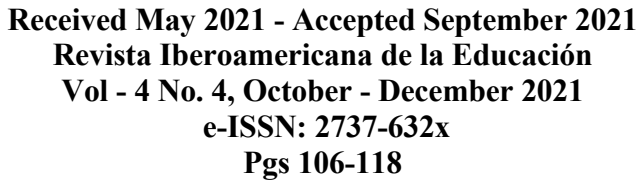

Abstract: The working conditions of the teaching profession constitute physical and psychosocial risk factors, which directly and indirectly affect professional performance and the significant increase in problems affecting the health of this study population. This bibliometric analysis on health and safety conditions in teachers is based on the analysis of 58 articles related to the subject, extracted from a search in the following databases: Scopus, Science Direct and Taylor \& Francis. For the above, the range of publications between 2012 and 2020 and the inclusion criteria were taken into account, the articles were analyzed under the following aspects: (1) analysis of the year and articles published, (2) analysis of authors, (3) country where the study was conducted (4) country of affiliation of each author and (5) analysis of 
journals where the articles were published. The scientific literature recognizes the different problems and occupational risk factors to which workers engaged in teaching and similar occupations are exposed, justifying the need and importance of addressing and recognizing the aspects that allow the promotion of health and the prevention of disease in this population.

Keywords: teaching personnel, Working conditions, blibliometrics, health and safety.

Resumen: Las condiciones laborales de la profesión docente constituyen factores de riesgo a nivel físico y psicosocial, las cuales inciden directa e indirectamente en el desempeño profesional y el significativo aumento de los problemas que afectan la salud en esta población en estudio. Este análisis bibliométrico sobre condiciones de seguridad y salud en docentes se realiza a partir del análisis de 58 artículos relacionados con la temática, extraídos de una búsqueda en las bases de datos: Scopus, Science Direct y Taylor \& Francis. Para lo anterior se tuvo en cuenta el rango de publicaciones entre el año 2012 y 2020 y los criterios de inclusión, los artículos fueron analizados bajo los siguientes aspectos: (1) análisis del año y artículos publicados, (2) análisis de autores, (3) país donde se realizó el estudio (4) País de filiación de cada autor y (5) análisis de revistas en donde se publicaron los artículos. Desde la literatura científica se reconocen los diferentes problemas y factores de riesgo laborales a los que están expuestos los trabajadores que se dedican al oficio de la docencia y similares, justificando la necesidad y la importancia de atender y reconocer los aspectos que permitan la promoción de la salud y la prevención de la enfermedad en esta población.

Palabras clave: personal docente, condiciones de trabajo, bibliometría, salud y seguridad. 
Resumo: As condições de trabalho da profissão docente constituem factores de risco físicos e psicossociais, que afectam directa e indirectamente o desempenho profissional e o aumento significativo de problemas que afectam a saúde da população deste estudo. Esta análise bibliométrica das condições de saúde e segurança nos professores baseia-se na análise de 58 artigos relacionados com o tema, extraídos de uma pesquisa nas seguintes bases de dados: Scopus, Science Direct e Taylor \& Francis. Para o acima exposto, a gama de publicações entre 2012 e 2020 e os critérios de inclusão foram tidos em conta, os artigos foram analisados sob os seguintes aspectos: (1) análise do ano e artigos publicados, (2) análise dos autores, (3) país onde o estudo foi realizado (4) país de afiliação de cada autor e (5) análise dos periódicos onde os artigos foram publicados. A partir da literatura científica, são reconhecidos os diferentes problemas e factores de risco profissional a que os trabalhadores da profissão docente e de profissões semelhantes estão expostos, justificando a necessidade e a importância de atender e reconhecer os aspectos que permitem a promoção da saúde e a prevenção de doenças nesta população.

Palavras-chave: pessoal docente, condições de trabalho, bibliometria, saúde e seguran

\section{INTRODUCTION}

Bibliometric tools contribute to research processes with different applied methods, in order to analyze and study scientific activities based on statistical and mathematical methods, achieving objectivity, measurement and comparison of each of them. Given the current research boom and its high cost, bibliometrics serves as a support for decision making, research direction and with a measurable basis to designate the necessary economic resources for research Dávila (2019). 
The significant increase in problems affecting mental health Seibt et al., (2005), the prevalence of musculoskeletal disorders (Ehsani et al., 2018; da Silva Vitor et al., 2017; Constantino et al., 2019), voice-related problems (Nazari et al., 2020; Cantor Cutiva et al., 2013; Sampaio et al., 2012; Giannini et al., 2015) and the presence of Burnout syndrome (Pando-moreno, 2006; Rodriguez et al., 2014; Wang et al., 2015; Ponce Díaz et al., 2014) are some of the many conditions that have been studied in teachers, understanding the interest for occupational health and safety, protection and prevention not only of the mentioned problems, but also of the diversity of risk factors that can affect these workers.

Constantino in a research conducted in Brazil, on musculoskeletal disorders (MSD), analyzed the disability in teachers and the prevalence of MSD, according to the data obtained $31.6 \%$ of teachers claim to have been diagnosed with a musculoskeletal disease, mostly in the regions of the neck, shoulders, lower back and upper back. Part of the research yields that "teachers who engage in leisure time physical activity are protected from MSDs in the same areas named above, compared to those who are inactive" (2019 p. 43). Regarding the prevalence of musculoskeletal disorders (MSDs) in higher education teachers, shoulder and back pain were found to be the common pattern of these conditions. However, neck pain and physical risk factors have a higher percentage of incidence compared to other MSDs, elbow pain despite not being as common has a prevalence of 3.5\% (Mohan et al., 2015, p. 243).

Poma et al. carried out an investigation in Peru with university teachers who were teleworking for the Covid-19 emergency, the most prevalent MSDs were mainly in the dorso-lumbar region (67.27\%), the neck $(64.55 \%)$, followed by the shoulder (44.55\%) and the wrist/hand (38.18\%). The authors associate pain in the dorsal-lumbar region and neck with prolonged postures 
typical of working hours, which include a working day of more than 10 hours a day, 5 to 7 days a week. Several studies indicate that working more than four hours in front of the computer generates symptoms in different segments of the body, most of which become painful, indicating that teachers who are teleworking are more exposed to developing MSDs (Poma, 2020). In Colombia, the Ministry of Labor established as mandatory the occupational health and safety management system as a logical and phased process that aims to "anticipate, recognize, evaluate and control risks that may affect health and safety" (occupational health and safety management system, 2020), of all work environments, including academic institutions, which are of vital interest for the development of research processes in the knowledge of the health status of teachers.

Based on the above, the following study conducts a bibliometric analysis of studies that have been done on health and safety conditions in teachers, which allow us to establish the importance given to this population. With the information, the following aspects were analyzed: (1) analysis of the year and articles published, (2) analysis of authors, (3) Authors who participated in the publication of each article (4) Country of each author (5) journals and publications and (6) Countries in which more journals were published.

\section{MATERIALS AND METHODS}

For the development of bibliometrics, original articles published in academic journals indexed in the Scopus, Taylor \& Francis and Science Direct databases and addressing topics related to the study of safety and health conditions in teachers were considered.

These documents were published in Spanish, Portuguese and English and corresponded to research results articles, review articles and mini-reviews found in the search carried out using Boolean operators "AND" "OR" 
between the categories ((teatching OR teachers) AND ("working conditions" OR "work effects" OR "occupational diseases") AND ("occupational health")).

Regarding the publication period, a total of 136 articles related to health and safety conditions in teachers were identified. During the process of reading the titles and abstracts, a total of 78 documents that did not meet the inclusion criteria were excluded; this phase was important to determine and make the decision to select the most relevant publications that were related to the research topic and the previously defined inclusion criteria.

At the end of this phase, the remaining 58 articles were read, all of which had terms related to the research topic and no document was excluded since they met the inclusion criteria. The development of bibliometrics was carried out through the analysis of the variables; year of publication, authors, authors' countries of affiliation and journal information, the data were exported and analyzed with Excel software.

\section{RESULTS}

The 58 articles selected for this research were published between 2012 and 2020, having as results the following publication data: from 2012 to 2014,8 articles related to the research topic were published, in 2015 there were 16 published articles, and from 2016 to 2017 there was a decrease in publications since only 12 articles were published, in 20185 articles were published, in 2019 there was an increase to 12 articles, ending in 2020 with 5 published articles.

The 58 publications were written by 176 different authors of various nationalities, $90.1 \%$ of the authors included in the bibliometrics have only one publication, 4\% have published two articles, and 2 authors; Mara Behlau from the Federal University of São Paulo has 3 publications and Fabiana Zambon, 
a speech therapist with a doctorate in human communication disorders from São Paulo, Brazil, has 4 publications. Regarding the authors' affiliation, we found that Brazil is the country with the highest representation of authors with $37 \%$, followed by the United Kingdom with $11 \%, 8 \%$ of authors belong to Germany, ending with $6 \%$ belonging to Italy and Malaysia. Countries such as China, Iran, Japan, Argentina, Colombia, among others, are represented by authors who participated in some publication, see Figure 1.

Figure 1. Country of Affiliation

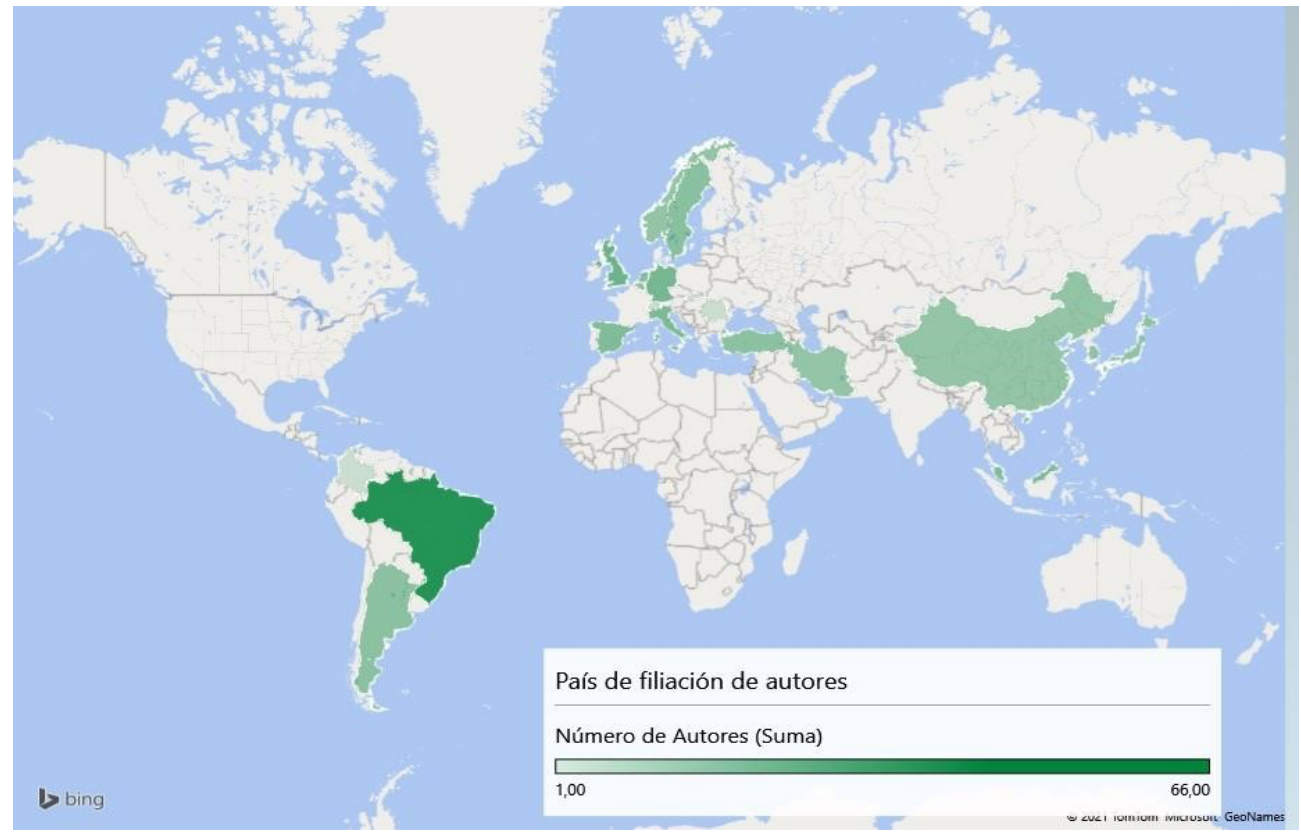

It is common that in scientific practice and in research processes, the different works and contributions are made in collaboration with various authors, this strengthens the richness and development of research methodology, allowing for multidisciplinary and interdisciplinary work in the sciences. For this bibliometrics, $87.9 \%$ of the articles included were written by at least 2 authors and only 7 persons wrote individually 7 of the 58 articles included. Figure 4 shows the frequency of the articles according to the number of authors who 
participated in them, it is important to mention that $18.9 \%$ of the manuscripts were developed by more than 5 authors.

The 58 articles included in this review were published by 29 different journals, the one with the highest participation is Procedia - Social and Behavioral Sciences, from the United Kingdom with 10 publications, followed by Codas Brazilian journal with 9 publications and Cadernos de Saúde Pública from Brazil with 5 publications. Table 1 shows the top 10 journals that published the most articles, recognizing that 18 journals only published one article included in this research.

Table 1. Journals with the most publications

\begin{tabular}{|c|c|c|c|c|c|c|c|}
\hline $\begin{array}{l}\text { Name of } \\
\text { magazine }\end{array}$ & $\begin{array}{c}\text { Publication } \\
\text { number }\end{array}$ & Index & SJR & Year & Country & Quartile & Thematic Area \\
\hline $\begin{array}{l}\text { Procedia - } \\
\text { Social and } \\
\text { Behavioral } \\
\text { Sciences }\end{array}$ & 10 & 46 & 0,15 & 2015 & $\begin{array}{l}\text { United } \\
\text { Kingdom }\end{array}$ & 0 & $\begin{array}{l}\text { Psychology } \\
\text { Psychology } \\
\text { (miscellaneous) } \\
\text { Social Sciences } \\
\text { Social Sciences } \\
\text { (miscellaneous) }\end{array}$ \\
\hline Codas & 9 & 20 & 0,37 & 2019 & Brazil & 1 & $\begin{array}{l}\text { Arts and Humanities } \\
\text { Language and } \\
\text { Linguistics } \\
\text { Health professions } \\
\text { Speech and hearing } \\
\text { Medication } \\
\text { Otorhinolaryngology }\end{array}$ \\
\hline $\begin{array}{l}\text { Cadernos de } \\
\text { Saúde Pública }\end{array}$ & 5 & 72 & 0,57 & 2019 & Brazil & 2 & $\begin{array}{l}\text { Medication } \\
\text { Medicine } \\
\text { (miscellaneous) } \\
\text { Public, } \\
\text { Environmental and } \\
\text { Occupational Health }\end{array}$ \\
\hline $\begin{array}{l}\text { Journal of } \\
\text { Voice }\end{array}$ & 3 & 83 & 0,8 & 2019 & USA & 1 & $\begin{array}{l}\text { Health professions } \\
\text { Speech and hearing } \\
\text { Medication } \\
\text { Otorhinolaryngology } \\
\text { Nursing } \\
\text { LPN and LVN }\end{array}$ \\
\hline
\end{tabular}




\begin{tabular}{|c|c|c|c|c|c|c|c|}
\hline $\begin{array}{l}\text { International } \\
\text { Journal of } \\
\text { Environmental } \\
\text { Research and } \\
\text { Public Health }\end{array}$ & 2 & 92 & 0,74 & 2019 & Switzerland & 2 & $\begin{array}{l}\text { Environmental } \\
\text { science Health, } \\
\text { toxicology and } \\
\text { mutagenesis } \\
\text { Contamination } \\
\text { Medication } \\
\text { Public, } \\
\text { environmental and } \\
\text { occupational health }\end{array}$ \\
\hline $\begin{array}{l}\text { Journal of } \\
\text { Work and } \\
\text { Organizational } \\
\text { Psychology }\end{array}$ & 2 & 61 & 1,81 & 2019 & $\begin{array}{l}\text { United } \\
\text { Kingdom }\end{array}$ & 1 & $\begin{array}{l}\text { Organizational } \\
\text { behavior and human } \\
\text { resource } \\
\text { management }\end{array}$ \\
\hline $\begin{array}{l}\text { Public Health } \\
\text { Research and } \\
\text { Practice }\end{array}$ & 2 & 24 & 0,55 & 2019 & Australia & 2 & $\begin{array}{l}\text { Medication } \\
\text { Public, } \\
\text { environmental and } \\
\text { occupational health }\end{array}$ \\
\hline $\begin{array}{l}\text { Brazilian } \\
\text { Journal of } \\
\text { occupational } \\
\text { medicine }\end{array}$ & 2 & 5 & 0,2 & 2019 & Brazil & 4 & $\begin{array}{l}\text { Medication } \\
\text { Physiology } \\
\text { (medical) }\end{array}$ \\
\hline $\begin{array}{l}\text { Collective } \\
\text { health }\end{array}$ & 2 & 11 & 0,33 & 2019 & Argentina & 3 & $\begin{array}{l}\text { Medication } \\
\text { Health policy } \\
\text { Public, } \\
\text { environmental and } \\
\text { occupational health }\end{array}$ \\
\hline $\begin{array}{l}\text { Scandinavian } \\
\text { Journal of } \\
\text { Management }\end{array}$ & 2 & 54 & 0,59 & 2019 & $\begin{array}{l}\text { United } \\
\text { Kingdom }\end{array}$ & 2 & $\begin{array}{l}\text { Business, } \\
\text { Management and } \\
\text { Accounting } \\
\text { Strategy and } \\
\text { management } \\
\text { Psychology } \\
\text { Applied Psychology }\end{array}$ \\
\hline
\end{tabular}

Journals are a channel of scientific communication, where professionals and researchers from different disciplines can make their findings known or be informed about new advances and discoveries, and exchange experiences (López et al. 2006). This article is a descriptive analysis of articles containing information on health and safety conditions in teachers, allowing the understanding and development of this field of knowledge, as well as the identification and analysis of the bibliometric characteristics of the published articles. The databases Scopus, Science Direct and Taylor \& Francis, were 
consulted and included in this research, yielding data of decrease in research articles on Occupational Health and Safety (OSH), (Collado, Soria, Canafoglia, \& Collado, 2016), according to experts in occupational psychopathology, it is necessary to evaluate occupational health as a complex process of social construction, in its various physical, psychological and emotional aspects, this will contribute to sustain the importance of research in this area.

During the bibliometric review it was possible to identify that within the articles found, the most frequent research topic was related to voice disorders, since it is the main working tool of teachers (Figueredo \& Castillo 2016), results such as voice-related problems (Nazari et al., 2020; Cantor Cutiva et al., 2013; Sampaio et al., 2012; Giannini et al., 2015), have given way to more research on this problem as indicated by (Sandoughdar \& Mohseni, 2016), in a research conducted in Iran which argues that teachers at the end of the working day suffer from vocal fatigue, because they have been speaking loudly for a long time and in the presence of high level background noise, it concludes that the overuse, abuse or misuse of the voice during teaching results in the achievement of an inadequate phonatory pattern, resulting in changes in the tissues of the teacher's voice.

Another condition that is more prevalent is the significant increase in problems affecting mental health (Seibt et al., 2005), Seibt agrees with Bannai et al. as he states that the increase in leave due to mental disorders among public school teachers in Japan, had an increase from 2,687 in 2002 to 4,960 in 2012 (Bannai, Ukawa, \& Tamakoshi, 2015).

The prevalence of musculoskeletal disorders is another common problem afflicting the health of teachers (Ehsani et al., 2018; da Silva Vitor et al., 2017; Constantino Coledam et al., 2019), with respect to this, a literature review on osteomuscular symptoms in teachers was found, which allows recognizing 
that the prevalence reports in the different studies are higher than $70 \%$, being the regions with more affectation the neck, shoulders and lumbar region, the risk factors identified are prolonged and maintained postures (Gómez Vélez, Leal Terranova, \& Arias Moreno, 2014).

The topics regarding the research area of the articles included are based on Medicine, Public, Environmental and Occupational Health with 15\%, followed by Medicine (miscellaneous) Pharmacology (medical) with 10\% and Medicine, Medicine (miscellaneous) Public, Environmental and Occupational Health with $10 \%$. Other studies have tried to describe the area of research with different classifications, the topics of the articles consulted in Brazil had a coverage of $41 \%$ on public health, environmental and occupational health, in the United Kingdom $76 \%$ on psychology and the USA with $75 \%$ on the topic of medicine, this shows that not all authors address the problem from the same topic and from a similar approach. The results of this analysis are related to what the authors consulted maintain in relation to the population group of education workers where the research is being carried out.

\section{CONCLUSIONS}

Bibliometric studies make it possible to recognize the progress of research being carried out in a given area.

\section{REFERENCES}

Bannai, A., Ukawa, S., \& Tamakoshi, A. (February 14, 2015). Long working hours and psychological distress among school teachers in Japan. Journal of Occupational Health. https://doi.org/10.1539/joh.14-0127$\mathrm{OA}$

Collado, P. A., Soria, C. B., Canafoglia, E., \& Collado, S. A. (2016). Working conditions and health in university and high school teachers in 
Mendoza, Argentina: between commitment and emotional exhaustion. Salud Colectiva. https://ri.conicet.gov.ar/bitstream/handle/11336/47894/CONICET_D igital_Nro.1ba1ae7ee140-4f9d-842d-

bf4ddb095840_A.pdf?sequence=2\&isAllowed $=y S e g \% C 3 \% B A n$

Constantino, D. H., Júnior, R. P., Ribeiro, E. A. G., \& de Oliveira, A. R. (2019). Factors associated with musculoskeletal disorders and disability in elementary teachers: A cross(da Silva Vitor et al., 2017)-sectional study. Journal of Bodywork and Movement Therapies, 23(3), 658-665. https://doi.org/10.1016/j.jbmt.2018.05.009

da Silva, J., Siqueira, L., Ribeiro, V. V., Ramos, J. S., Brasolotto, A. G., \& Silverio, K. (2017). Musculoskeletal Pain and Occupational Variables in Teachers With Voice Disorders and in Those With Healthy VoicesA Pilot Study. Journal of voice : official journal of the Voice Foundation, 31(4),518.e7-518.e13. https://doi.org/10.1016/j.jvoice.2016.12.021

Ehsani, F., Mohseni-Bandpei, M. A., Fernández-De-Las-Peñas, C., \& Javanshir, K. (2018). Neck pain in Iranian school teachers: Prevalence and risk factors. Journal of Bodywork and Movement Therapies, 22(1), 64-68. https://doi.org/10.1016/j.jbmt.2017.04.003.

Figueredo, J. N., \& Castillo Martínez, J. A. (2016). Assessment of vocal disorders in professionals who use their voice as a work tool. Occupational Voice Quick Screening. Health Sciences Journal. Retrieved from https://revistas.urosario.edu.co/index.php/revsalud/article/view/5081

Giannini, S. P. P. P., Latorre, M. D. R. R. D. D. D. O., Fischer, F. M., Ghirardi, A. C. D. A. A. M., \& Ferreira, L. P. (2015). Teachers' voice disorders and loss of work ability: A case-control study. Journal of Voice, 29(2), 209-217. https://doi.org/10.1016/j.jvoice.2014.06.004.

Gómez, D. F., Leal Terranova, O. E., \& Arias, P. (2014). Musculoskeletal symptoms in teachers: A review of the literature. Colombian Journal of Occupational Health. https://doi.org/10.18041/2322634X/rcso.2.2014.4911.

Manuel Dávila Rodríguez, R. G.-U. (2019). Bibliometrics: concepts and utilities for the. Salud Uninorte. http://www.bibliotecaminsal.cl/wp/wpcontent/uploads/2015/07/Bibliometria-conceptos-y-utilidades.pdf 
Pando-Moreno, M., Castañeda-Torres, J., Gregoris-Gómez, M., \& Aguila, A. (2006). Psychosocial factors and burnout syndrome in teachers at the Universidad del Valle de Atemajac, Guadalajara, Mexico. Salud En Tabasco, 12(3), 523-259.

Nazari, M., Dastoorpoor, M., Ghasemzadeh, R., \& Moradi, N. (2020). Relationship Between Work Engagement and Voice Complaints Among Elementary School Teachers. Journal of Voice, 1-5. https://doi.org/10.1016/j.jvoice.2019.12.001

Poma, E. E. (2020). Prevalence of musculoskeletal disorders in university teachers who perform telework in times of Covid - 19. Naspa Fournal

Ponce, C. R., Bulnes, M. S., Aliaga, J. R., Atalaya, M. C., \& Huerta, R. E. (2014). The "burnout" syndrome due to assistive work stress in groups of university teachers. Revista de Investigación En Psicología, 8(2), 87. ttps://doi.org/10.15381/rinvp.v8i2.4050

Rodríguez, C., Hinojosa, M., Marina, L., Ramírez, G., Teresa, M., Marina, L., \& Hinojosa, M. (2014). Performance, stress, burnout and personal variables of university teachers. Educere, 18(60), 289-302.

Sandoughdar, N., \& Mohseni, R. (July 04, 2016). Survey of acoustic voice parameters in Iranian female teachers. Voice journal. Retrieved from https://doi.org/10.1016/j.jvoice.2015.05.020

Seibt, R. T., L, L., \& Thinschmidt, M. (2005). teachers and clerks. 1280, 310 315.

Occupational Health and Safety Management System. (August 28, 2020). Ministry of Labor. Retrieved from Ministry of Labor: https://www.mintrabajo.gov.co/relacioneslaborales/riesgoslaborales/sistema-de-gestion-de-seguridad-y-salud-en-el-trabajo

Wang, Y., Ramos, A., Wu, H., Liu, L., Yang, X., Wang, J., \& Wang, L. (2015). Relationship between occupational stress and burnout among Chinese teachers: a cross-sectional survey in Liaoning, China. International Archives of Occupational and Environmental Health, 88(5), 589-597. https://doi.org/10.1007/s00420-014-0987-9.

Zamora-Díaz, W. J., Cobos, D., \& López Noguero, F. (2017). Conditions

Social and occupational health of Nicaraguan secondary school teachers. Revista de Pedagogia. Retrieved from https://www.redalyc.org/pdf/659/65954978010 